\title{
Biochemical Profile, In vitro Toxicity, and Cytotoxic activity of Eragrostis amabilis (L.) Wight. Arn. and Eragrostis pilosa (L.) Beauve
}

\author{
Mani Sujatha 1,\#(D), Marimuthu Antonysamy Johnson 1(D), Durairaj Vanila ${ }^{2}$ (D), Ray Silva Almeida ${ }^{3}$, \\ Henrique Douglas Melo Coutinho ${ }^{3, * \text { (D) }}$
}

1 Centre for Plant Biotechnology, Department of Botany, St. Xavier's College (Autonomous), Palayamkottai, Tamil Nadu, 627 002, India; ptcjohnson@gmail.com (M.J.); msujatha631983@gmail.com (M.S.);

\# Reg. No. 12196, Affiliated to Manonmaniam Sundaranar University, Abishekapatti-627012, Tamil Nadu, India

2 Department of Botany, T.D.M.N.S. College, T. Kallikulam, Tirunelveli, Tamil Nadu, India; vanilatdmns20@gmail.com (D.V.);

3 Laboratory of Microbiology and Molecular Biology, Regional University of Cariri-URCA, Crato 63105-000, CE, Brazil. rayalmeidasilva2306@gmail.com (R.S.A.); hdmcoutinho@gmail.com (H.D.M.C.);

* Correspondence: hdmcoutinho@gmail.com (H.D.M.C.);

Scopus Author ID 35236795400

Received: 25.06.2021; Revised: 30.07.2021; Accepted: 3.08.2021; Published: 5.09.2021

Abstract: The present study is intended to reveal the biochemical profile and assess the toxicity and cytotoxic activity of aerial and underground parts of Eragrostis amabilis (L.) Wight. Arn. and Eragrostis pilosa (L.) Beauv. extracts using Brine shrimp lethality bioassay and Dalton's lymphoma ascites cell (DLA). The maximum amount of protein $31.2 \mathrm{mg} / \mathrm{g}$, amino acid $50.5 \mathrm{mg} / \mathrm{g}$, glucose 62.8 $\mathrm{mg} / \mathrm{g}$ and Indole acetic acid $29.5 \mathrm{mg} / \mathrm{g}$ were found in E. amabilis aerial parts. The maximum amount of total phenolics $(218.21 \mathrm{mg} / \mathrm{g})$ and tannins $(88.5 \mathrm{mg} / \mathrm{g})$ was observed in ethanolic extracts of E. amabilis aerial parts. The highest value of flavonoids was stated in chloroform extracts of E. amabilis underground parts $(544 \mathrm{mg} / \mathrm{g})$. The maximum amount of total phenolics and total tannin was observed in ethyl acetate extracts of $E$. pilosa aerial parts. The highest amount of flavonoids was found in ethyl acetate extracts of E. pilosa underground parts. The toxicity ( $\mathrm{LC}_{50}$ values) of E. amabilis aerial and underground parts were ranged from $0.48-1.52 \mathrm{mg} / \mathrm{mL}$ and $0.012-1.154 \mathrm{mg} / \mathrm{mL}$ respectively. The $\mathrm{LC}_{50}$ value of $E$. pilosa aerial and underground parts extract was ranged from $1.089-1.904 \mathrm{mg} / \mathrm{mL}$ and $0.038-1.726 \mathrm{mg} / \mathrm{mL}$. The high cytotoxicity $\left(\mathrm{ICT}_{50}\right)$ was observed in ethyl acetate extracts of E. amabilis and E. pilosa.

Keywords: phytoprofile; flavonoids; phenols; toxicity; cytotoxicity.

(C) 2021 by the authors. This article is an open-access article distributed under the terms and conditions of the Creative Commons Attribution (CC BY) license (https://creativecommons.org/licenses/by/4.0/).

\section{Introduction}

The grasses possess primary (crude proteins, carbohydrates, and fats) and secondary metabolites ( $\beta$-sitosterol, flavanoids, alkaloids, glycosides, triterpenoids) for their sustainable establishment in the ecosystem. In addition, they possess the mineral constituents' viz., oxides of magnesium, phosphorous, calcium, sodium, and potassium, and other compounds like vitamin C, carotene, etc. Green grass contain $10.47 \%$ crude protein, $28.17 \%$ fiber, and $11.75 \%$ of total ash [1].

Some monocots like Allium cepa, Allium sativum, and Zea mays showed important compounds like alkaloids, flavonoids, phenolic compounds, saponins, steroids, tannins, 
terpenoids etc. [1]. Coffie et al. (2014) studied the phytochemical composition of wet and dry states of Bambusa vulgaris, Bambusa ventricos, and Oxytenanthera abyssinica leaves confirmed the existence of saponins, general glycosides, coumarins, and cyanogenic glycosides [2]. Megha et al. (2016) revealed carbohydrates, tannins, steroids, terpenoids, alkaloids, flavonoids, cardiac glycosides, saponins, coumarins, amino acids, etc., in the Eragrostis plana Nee. leaves extracts [3].

The presence of alkaloids, tannins, and phenolics in the methanolic extracts of Leptochloa uniflora Hochst fresh leaves was confirmed [4]. The phytochemical study revealed flavonoids, alkaloids, and steroids in Cymbopogon coloratus, Cynodon dactylon, Panicum repens, and Sporobolus wallichii [5]. Cymbopogon citratus is well exploited in the pharmaceutical industry [6]. Favaretto et al. (2015) revealed the occurrence of alkaloids, anthraquinones, flavonoids, tannins, and saponins in the tough love grass extracts [7]. Flavonoids, lactones, and certain phenolic acids are the main chemical constituents of bamboo leaves [8].

Eragrostis tenella (Poaceae), phenolic acids, glycosides, flavonoids, alkaloids, leuco anthocyanidins, saponins, fatty acids, steroids, and emodins presence were reported [9]. But there is no report on the biochemical composition of Eragrostis amabilis and Eragrostis pilosa. With this knowledge, the present study was carried out to find the quantitative and qualitative phytoprofile of Eragrostis amabilis (L.) Wight. Arn. and Eragrostis pilosa (L.) Beauv. aerial and underground parts extracts.

The brine shrimp lethality bioassay (BSLB) has been employed to measure the toxicity of the plant crude extracts or isolated compounds. BSLB assay has been exploited to predict the pesticide residues, mycotoxins, stream pollutants, anesthetics, morphine-like compounds, the carcinogenicity of phorbol esters, and toxicants in the marine environment. A number of novel antitumor and pesticide natural products have been isolated using this bioassay [10,11]. The in vitro anticancer potential of aqueous and ethanolic extracts of Cyperus rotundus (L.) showed great effects [12]. But there is no report on the toxicity and cytotoxicity of aerial and underground parts of Eragrostis amabilis (L.) Wight. Arn. and Eragrostis pilosa (L.) Beauv. different extracts.

The objective of the present study is to assess the toxicity and cytotoxic activity of aerial and underground parts of Eragrostis amabilis (L.) Wight. Arn. and Eragrostis pilosa (L.) Beauv. extracts using Brine shrimp lethality bioassay and Dalton's lymphoma ascites cell (DLA).

\section{Materials and Methods}

\subsection{Collection of plant samples.}

The whole plants of Eragrostis amabilis (L.) Wight. Arn. and Eragrostis pilosa (L.) Beauv. were collected from A. Thirumalapuram, Tirunelveli district, Tamil Nadu, South India. The plants were washed with tap water to remove the soil and other debris. The aerial and underground parts of E. amabilis and E. pilosa were separated properly and dried under shade conditions at room temperature for fifteen days. The dried samples (aerial and underground parts) were grounded to a fine powder using a mechanical grinder. The powdered sample was then stored in a refrigerator at $7^{\circ} \mathrm{C}$ for further analysis. 


\subsection{Preparation of extract.}

The dried and powdered aerial and underground plant parts (30 g) of Eragrostis amabilis (L.) and Eragrostis pilosa (L.) were extracted with $400 \mathrm{ml}$ of petroleum ether, acetone, chloroform, ethanol, and ethyl acetate by using a soxhlet extractor for $12 \mathrm{hrs}$ at a room temperature not exceeding the boiling point of the solvents. After $12 \mathrm{hrs}$, the extracts were collected in Petri dishes and evaporated the excess solvents. The obtained residues of the plant extracts were stored in sterile bottles for further analysis.

\subsection{Quantitative determination of primary metabolites.}

According to the following literature report, the total glucose, the amino acid, protein concentration, and the indole acetic acid were determined, respectively [13-16].

\subsection{Quantitative determination of secondary metabolites.}

\subsubsection{Estimation of flavonoids.}

The total flavonoid content of aerial and underground parts of E. amabilis and E. pilosa was estimated by Zhishen et al. (1999) [17]. The results are expressed as mg of flavonoids as quercetin equivalent/gm of dried sample.

\subsubsection{Determination of total phenolics and Tannins.}

The total flavonoid content of aerial and underground parts was estimated by the method described by Siddhuraju and Becker (2003) [18]. The tannin content of the sample was calculated as follows:

$$
\text { Tannins }(\%)=\text { Total phenolics }(\%)-\text { Non-tannins phenolics }(\%)
$$

\subsubsection{Estimation of total terpenoids and total sterols.}

The total concentration of terpenoids and sterols was determined according to the methodology described by Johnson et al. (2020) [19].

\subsection{Toxicity analysis.}

\subsubsection{Preparation of samples.}

The toxicity analysis was carried out with five test tubes for each concentration of $E$. amabilis and E. pilosa various extracts ( $5 \times 10$ nauplii $=50$ nauplii / concentration) and 5 tubes for control and performed according to the method described by (McLaughlin and Rogers 1988) [20]. Tubes without the extract were added to prepare the control solution. After 24 hours, the number of survived nauplii in each tube was counted, and $\mathrm{LC}_{50}, \mathrm{LC} 90, \mathrm{LCL}$, and UCL values were calculated.

\subsubsection{In vitro cytotoxicity (anticancer activity).}

The test compounds were studied for short-term in vitro cytotoxicity using Dalton's lymphoma ascites cell [21]. These assay mixtures were incubated for $3 \mathrm{~h}$ at $37^{\circ} \mathrm{C}$. The further cell suspension was mixed with $0.1 \mathrm{ml}$ of $1 \%$ trypan blue, kept for $2-3$ minutes, and loaded on 
a hemocytometer. Dead cells take up the blue color of trypan blue, and white live cells do not take up the dye. The numbers of stained or unstained cells were counted separately, and the cytotoxicity was determined by:

$\%$ of Cytotoxicity $=$ No of dead cells $/$ No of live cells + number of dead cells x100

\section{Results and Discussion}

\subsection{Quantification of primary metabolites.}

The estimated total protein, amino acid, glucose, and Indole acetic acid of E. amabilis and E. pilosa aerial and underground parts were illustrated in Fig. 1. The maximum amount of protein $31.2 \mathrm{mg} / \mathrm{g}$, amino acid $50.5 \mathrm{mg} / \mathrm{g}$, glucose $62.8 \mathrm{mg} / \mathrm{g}$, and indol acetic acid $29.5 \mathrm{mg} / \mathrm{g}$ were found in E. amabilis aerial parts.

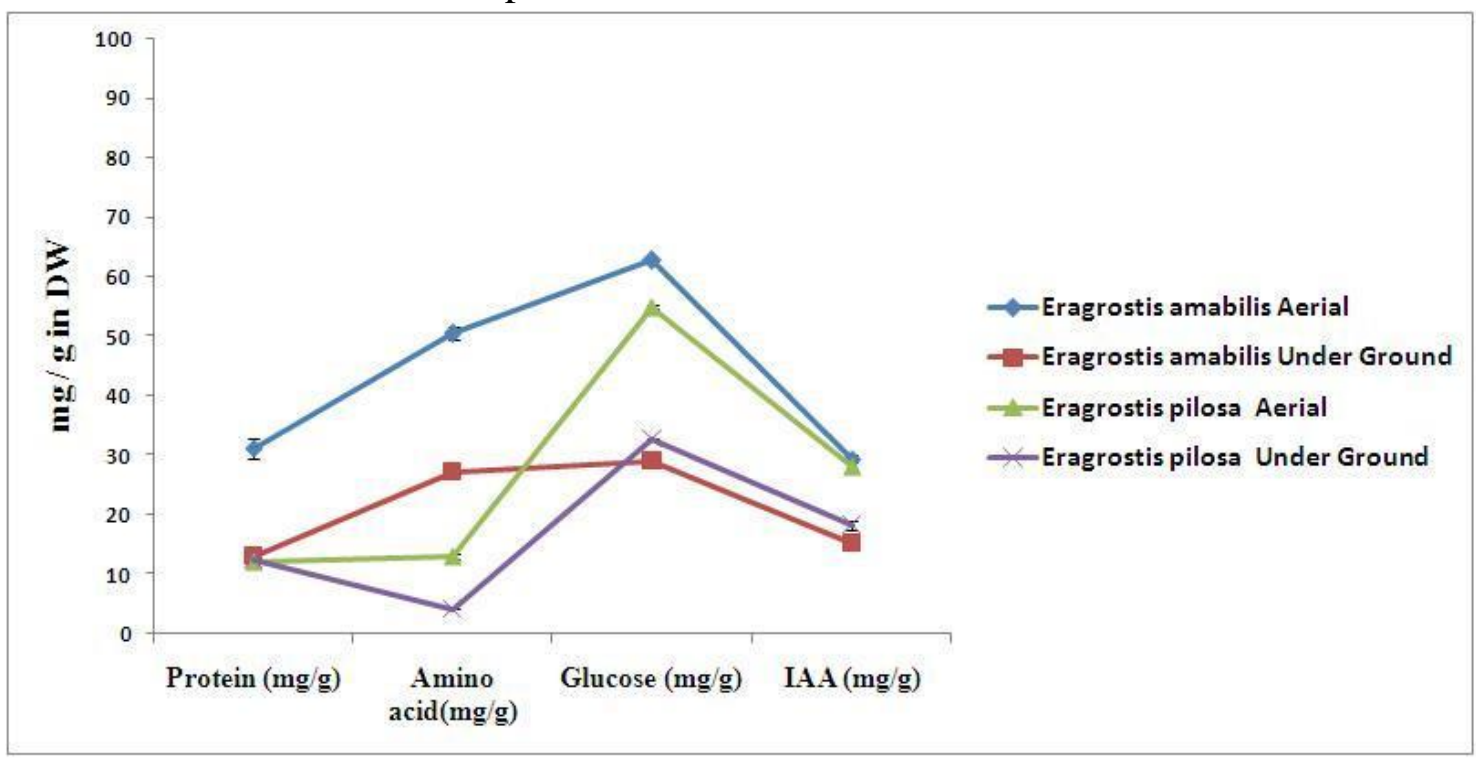

Figure 1. Biochemical profile of E. amabilis and E. pilosa.

\subsection{Total phenolics contents of E. amabilis aerial and underground parts.}

The total extractable total phenolics, tannins, flavonoids, and triterpenoids of $E$. amabilis aerial and underground parts were demonstrated in Fig. 2. The maximum amount of total phenolics $(218.21 \mathrm{mg} / \mathrm{g})$ was observed in ethanolic extracts of E. amabilis aerial parts, and the least value $(151 \mathrm{mg} / \mathrm{g})$ was noticed in E. amabilis underground parts acetone extracts. The highest amount of tannins $(88.5 \mathrm{mg} / \mathrm{g})$ was observed in ethanolic extracts of E. amabilis aerial parts. The chloroform extracts of E. amabilis underground parts showed a minimum amount of tannins $(17 \mathrm{mg} / \mathrm{g}$ ). The highest value of flavonoids was stated in chloroform extracts of E. amabilis underground parts $(544 \mathrm{mg} / \mathrm{g})$. Ethyl acetate extracts of E. amabilis underground parts revealed the minimum amount of flavonoids $(65.7 \mathrm{mg} / \mathrm{g})$. Among the observed values, ethyl acetate extracts of $E$. amabilis aerial parts showed the highest terpenoids ( $285 \mathrm{mg} / \mathrm{g}$ ), and petroleum ether extract of $E$. amabilis aerial parts revealed the least amount of terpenoids (94.8 $\mathrm{mg} / \mathrm{g})$. The maximum amount of sterols $(7.36 \mathrm{mg} / \mathrm{g})$ was found in ethanolic extracts of $E$. amabilis aerial parts, and a minimum amount $(1.73 \mathrm{mg} / \mathrm{g})$ was observed in acetone extracts of E. amabilis underground parts. 


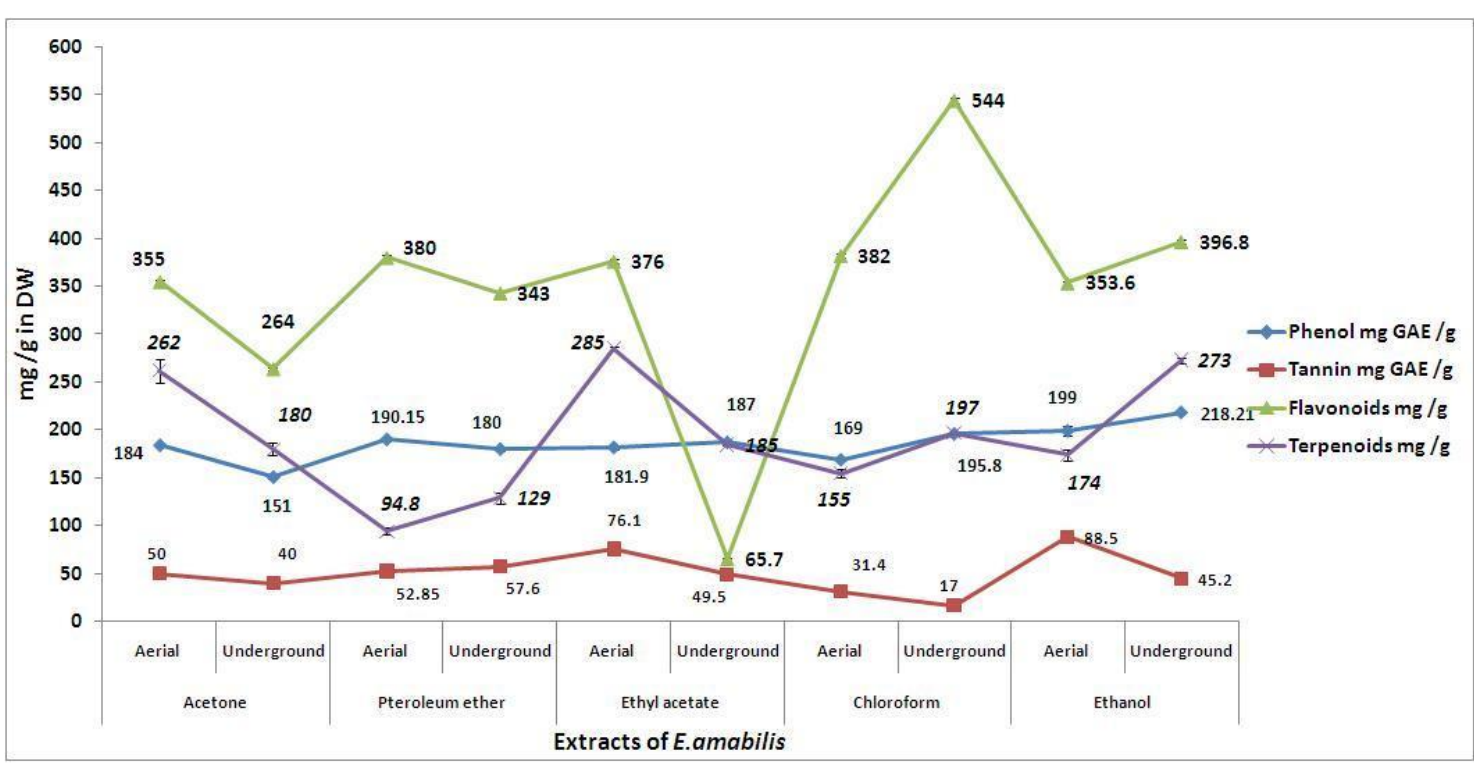

Figure 2. Secondary metabolites of E. amabilis (mg/g in DW).

\subsection{Total phenolics contents of E. pilosa aerial and underground parts.}

The total extractable total phenolics, tannins, flavonoids, and triterpenoids of E. pilosa aerial and underground parts were illustrated in Fig. 3. The maximum amount of total phenolics was observed in ethyl acetate extracts of E. pilosa aerial parts $(197 \mathrm{mg} / \mathrm{g})$. Whereas acetone, chloroform, ethyl acetate, and petroleum ether extracts of E. pilosa aerial and underground parts demonstrated moderate levels of phenolics. Among the tested extracts of E. pilosa, total tannin was the highest in ethanolic extracts of E. pilosa aerial parts $(64.5 \mathrm{mg} / \mathrm{g})$ and least in ethyl acetate extracts of $E$. pilosa underground parts $(18.95 \mathrm{mg} / \mathrm{g})$. The highest amount of flavonoids was found in ethyl acetate extracts of E. pilosa underground parts $(289.5 \mathrm{mg} / \mathrm{g})$. The lowest $(127.8 \mathrm{mg} / \mathrm{g}$ ) was observed in the ethanolic extracts E. pilosa underground parts. Among the observed values, ethyl acetate extracts of E. pilosa aerial parts showed maximum terpenoids (265 mg/g), and petroleum ether extracts of E. pilosa underground parts showed the least amount of terpenoids $(119.3 \mathrm{mg} / \mathrm{g})$. The highest amount of sterols was revealed in ethyl acetate extracts of E. pilosa aerial parts $(33.8 \mathrm{mg} / \mathrm{g})$, and the least amount $(14.6 \mathrm{mg} / \mathrm{g})$ was obtained in the acetone extracts of E. pilosa underground parts.

Brine shrimp lethality bioassay method was used to determine the general toxic properties of E. amabilis and E. pilosa aerial and underground parts. The toxicity ( $\mathrm{LC}_{50}$ values) of E. amabilis aerial parts were as follows: ethyl acetate extracts $(0.48 \mathrm{mg} / \mathrm{mL})>$ acetone $(0.85$ $\mathrm{mg} / \mathrm{mL})>$ chloroform $(1.18 \mathrm{mg} / \mathrm{mL})>$ petroleum ether $(1.42 \mathrm{mg} / \mathrm{mL})>$ ethanol $(1.52 \mathrm{mg} /$ $\mathrm{mL}$ ). The toxicity ( $\mathrm{LC}_{50}$ values) of E. amabilis underground parts extracts were as follows: ethyl acetate $(0.012 \mathrm{mg} / \mathrm{mL})>$ petroleum ether $(0.70 \mathrm{mg} / \mathrm{ml})>$ ethanol $(1.112 \mathrm{mg} / \mathrm{ml})>$ acetone $(1.133 \mathrm{mg} / \mathrm{ml})>$ chloroform $(1.154 \mathrm{mg} / \mathrm{mL})$. The $\mathrm{LC}_{50}$ value of E. pilosa aerial parts extract were as follows: ethyl acetate $(1.089 \mathrm{mg} / \mathrm{mL})>$ chloroform $(1.302 \mathrm{mg} / \mathrm{mL})>$ petroleum ether $(1.423 \mathrm{mg} / \mathrm{mL})>$ acetone $91.464 \mathrm{mg} / \mathrm{ml})>$ ethanol $(1.904 \mathrm{mg} / \mathrm{mL})$. The $\mathrm{LC}_{50}$ value of E. pilosa under ground parts extract were as follows: ethyl acetate $(0.038 \mathrm{mg} / \mathrm{mL})>$ petroleum ether $(0.071 \mathrm{mg} / \mathrm{mL})>$ acetone $(1.048 \mathrm{mg} / \mathrm{mL})>$ chloroform $(1.397 \mathrm{mg} / \mathrm{mL})>$ ethanol $(1.726 \mathrm{mg} / \mathrm{mL})$. Based on the results of toxicity analysis, the ethyl acetate extracts of E. amabilis and E. pilosa aerial and underground parts were screened for the cytotoxicity against Dalton's lymphoma ascites cell (DLA). Among the tested extracts, the aerial parts of E. amabilis and E. pilosa possess more activity than underground parts. The cytotoxicity 
(ICT 50 ) of ethyl acetate extracts of E. amabilis and E. pilosa aerial and underground parts were as follows: E. amabilis aerial parts $(50.81 \mathrm{mg} / \mathrm{mL})>$ E. pilosa aerial parts $(51.5 \mathrm{mg} / \mathrm{mL})>\mathrm{E}$. amabilis underground parts $(60.31 \mathrm{mg} / \mathrm{mL})>$ E. pilosa underground parts $(76.6 \mathrm{mg} / \mathrm{mL})$.

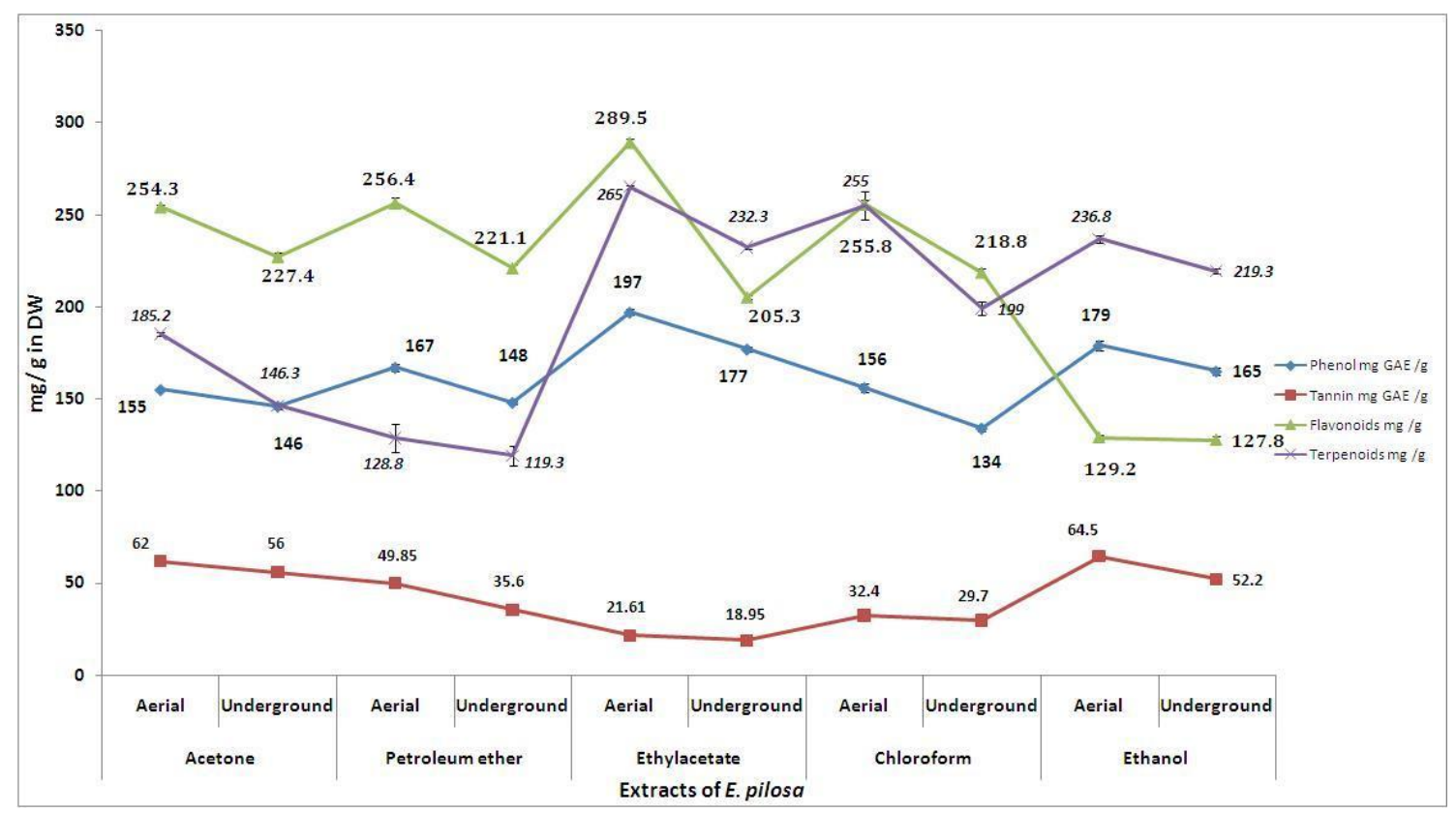

Figure 3. Phytoprofile of E. pilosa (mg/g in DW).

\subsection{Discussion.}

The primary metabolites (protein, amino acids, and glucose) existence was high in the aerial parts of E. amabilis and E. pilosa. Similarly, the amount of Indole acetic acid (IAA) existence also varied concerning parts. IAA plays a vital role in regulating plant growth and development processes, cell elongation, cell division, and the formation of meristems. Due to the presence of more meristematic regions, the aerial parts of E. amabilis and E. pilosa showed more amount of IAA than underground parts of E. amabilis and E. pilosa. The medicinal properties of the plant extracts are predominantly governed by the presence of bioactive constituents like phenolics, flavonoids, and others [20]. For ecological adaptation, survival, and protection, the plants are endowed with various phytoconstituents such as vitamins, terpenoids, phenolics, lignins, tannins, flavonoids, quinines, alkaloids, and other metabolites [21].

The presence of secondary metabolites with varying amounts is due to the solvent polarity (petroleum ether, acetone, chloroform, ethyl acetate, and ethanol) and inbound chemical constituents of the aerial and underground parts of E. amabilis and E. pilosa showed (Fig. 1-3). Phenolic compounds are widely distributed in plants, possessing various biological activities, such as anti-inflammatory, antidiabetic, anticancer, and antimicrobial [22, 23]. Flavonoids also possess anti-inflammatory, antidiabetic, and antimicrobial activities [24]. Boonya-udtayan et al. (2019) summarized the serratene-type triterpenoids and biological activities viz., cytotoxicity, and chemopreventive activity [25].

The present study results revealed the presence of secondary metabolites such as phenols, tannins, flavonoids, terpenoids, and sterols in the E. amabilis and E. pilosa aerial and underground parts extracts. Previous observations on the biological activities of secondary metabolites suggest that the studied E. amabilis and E. pilosa aerial and underground parts may possess antioxidant, anti-inflammatory, anticancer, antidiabetic, and antimicrobial activities. To confirm the biological properties of E. amabilis and E. pilosa aerial and underground parts, 
the toxicity analysis using the brine shrimp lethality bioassay (BSLB) was carried out. McLaughlin et al. (1982) predicted the antitumor and pesticide properties of the plant extracts using BSLB assay.

The toxicity study results suggest that E. amabilis and E. pilosa aerial and underground parts may possess antitumor and pesticide properties. To confirm the antitumor properties of the ethyl acetate extracts of E. amabilis and E. pilosa, aerial and underground parts were subjected to cytotoxicity analysis against Dalton's lymphoma ascites cell. Similarly, Vijayalakshmi et al. (2012) studied the cytotoxic effects of Trticum aestivum ethanolic extract against the A549 cell line in vitro [26]. Garima et al. (2014) screened the cytotoxic properties of Wheat grass methanolic extracts [28]. They observed significant cytotoxicity and confirmed that phenols and flavonoids' presence in the methanolic extracts is responsible for the cytotoxic property. Hema et al. (2016) observations also identified the role of phenolics and flavonoids cytotoxicity and anticancer potential of Cyperus rotundus [12]. In the present investigation, the high frequency of anticancer potential was observed in the phenol, flavonoids, and tannins rich E. amabilis and E. pilosa aerial parts ethyl acetate extracts. Similar to the present investigation, Cynodon dactylon ethyl acetate extracts showed greater anticancer activity [28].

\section{Conclusions}

The present study results confirmed the cytotoxic potential of E. amabilis and E. pilosa; further studies on these crude extracts may bring out an alternative drug for cancer treatment.

\section{Funding}

This research received no external funding.

\section{Acknowledgments}

This research has no acknowledgment.

\section{Conflicts of Interest}

The authors declare no conflict of interest.

\section{References}

1. Joshi, A.; Chauhan, R. Phytochemical Analysis and Cytotoxicity Studies of Curcuma amada rhizomes in BHK-21 Cells. International Journal of Scientific Research in Environmental Sciences 2013, 1, 365-371.

2. Coffie, G.; Antwi-Boasiako, C.; Darkwa, N. Phytochemical constituents of the leaves of three bamboo (Poaceae) species in Ghana. Journal of Pharmacognosy and Phytochemistry 2014, 2, 34-38.

3. Megha, M.; Archa-Raj, M.; Akhil, S.A.; Liji, R.S.; Sruthy, S.K.; Anju, M.N.; Neethu, S.K. Preliminary Phytochemical Analysis of Wheat Grass Leaf Extracts. Int. J Pharm. Sci 2016, 40, 307-312.

4. Johnson, M.; Janakiraman, N.; Murugesan, S. Studies on Antioxidant and Phytochemical Profiles of Leptochloa uniflora Hochst. IBBJ 2015, 1, 146-156.

5. Hari, B.R.; Savithramma, N. Phytochemical screening of underutilized species of Poaceae. JPR: BioMedRx: An International Journal 2013, 1, 947-951.

6. Avoseh, O.; Oyedeji, O.; Rungqu, P.; Nkeh-Chungag, B.; Oyedeji, A. Cymbopogon Species; Ethnopharmacology, Phytochemistry and the Pharmacological Importance. Molecules 2015, 20, 7438-7453, https://doi.org/10.3390/molecules20057438.

7. Favaretto, A.; Chini, S.; Scheffer-basso, S.; Sobottka, A.; Bertol, C.; Perez, N. Pattern of allelochemical distribution in leaves and roots of tough lovegrass (Eragrostis plana Nees.). Australian Journal of Crop Science 2015, 9, 1119-1125.

8. Zhang, Z.-Y.; Yang, D.-Z.; Lu, A.-M.; Knapp, S. Seed morphology of the tribe Hyoscyameae (Solanaceae). Taxon 2005, 54, 71-83, https://doi.org/10.2307/25065303. 
9. Ankanna, S.; Suhrulatha, D.; Savithramma, N. Allelopathy and Allelochemicals of Eragrostis plana (Poaceae) and Its Relation with Phenology and Nitrogen Fertilization. Planta Daninha 2017, 35, https://doi.org/10.1590/S0100-83582017350100028.

10. McLaughlin, J.L. Brine shrime: a convenient general bioassay for active constituents. Planta Medica 1982, 45, 31-32.

11. McLaughlin, J.L.; Rogers, L.L.; Anderson, J.E. The Use of Biological Assays to Evaluate Botanicals. Drug information journal:DIJ/Drug Information Association $\quad \mathbf{1 9 9 8 ,} \quad 32, \quad 513-524$, https://doi.org/10.1177/009286159803200223.

12. Hema, N.; Avadhani, R.; Ashwini, P.; Ravishankar, B. In vitro cytotoxic activity of rhizome extracts of Cyperus rotundus (L.) against colon carcinoma and Ehrlich ascites carcinoma. Journal of Applied Pharmaceutical Science 2016, 6, 172-175, https://doi.org/10.7324/JAPS.2016.601127.

13. Sumner, J.B.; Graham, V.A. Dintrosalicylic acid: A reagent for the estimation of Sugar in Normal and Diabetic Urine. J. Biol. Chem 1921, 47, 5-9.

14. Yemm, E.W.; Cocking, E.C.; Ricketts, R.E. The determination of amino-acids with ninhydrin. Analyst 1955 , 80, 209-214, https://doi.org/10.1039/an9558000209.

15. Lowry, O.H.; Rosebrough, N.J.; Farr, A.L.; Randall, R.J. Protein measurement with the Folin phenol reagent. The Journal of biological chemistry 1951, 193, 265-275.

16. Gordon, S.A.; Weber, R.P. Colorimetric Estimation of indoleacetic Acid. Plant Physiology 1951, 26, $192-$ 195, https://doi.org/10.1104/pp.26.1.192.

17. Zhishen, J.; Mengcheng, T.; Jianming, W. The determination of flavonoid contents in mulberry and their scavenging effects on superoxide radicals. Food Chemistry 1999, 64, 555-559, https://doi.org/10.1016/S0308-8146(98)00102-2.

18. Siddhuraju, P.; Becker, K. Studies on antioxidant activities of mucuna seed (Mucuna pruriens var utilis) extract and various non-protein amino/imino acids through in vitro models. Journal of the Science of Food and Agriculture 2003, 83, 1517-1524, https://doi.org/10.1002/jsfa.1587.

19. Johnson, M.A.; Madona, C.X.; Almeida, R.S.; Martins, N.; Coutinho, H.D.M. In Vitro Toxicity, Antioxidant, Anti-Inflammatory, and Antidiabetic Potential of Sphaerostephanos unitus (L.) Holttum. Antibiotics 2020, 9 , 333-345.

20. McLaughlin, J.L.; Rogers, L.L.; Anderson, J.E. The Use of Biological Assays to Evaluate Botanicals. Drug Information Journal 1998, 32, 513-524, https://doi.org/10.1177/009286159803200223.

21. Chon, O.; Keo, S.; Sonita, L.; Chanseiha Lim, S.; Chean, K.; Ung, H.; Maneenet, J. Phytotaxonomy and phytochemicals of Eight species of the Family Moraceae. International Journal of Scientific \& Engineering Research 2016, 7.

22. Biradar, Y.S.; Jagatap, S.; Khandelwal, K.R.; Singhania, S.S. Exploring of Antimicrobial Activity of Triphala Mashi-an Ayurvedic Formulation. Evid Based Complement Alternat Med 2008, 5, 107-113, https://doi.org/10.1093/ecam/nem002.

23. Holderbaum, D.F.; Kon, T.; Guerra, M.P. Dynamics of total phenolic content in different apple tissues and genotypes: impacts and relevance for breeding programs. Scientia Horticulturae 2014, 168, 58-63, https://doi.org/10.1016/j.scienta.2014.01.020.

24. Dragana, Z.J.; Vasić, S.M.; Stanković, M.S.; Čomić, L.R.; Topuzović, M.D. Secondary metabolite content and in vitro biological effects of Ajuga chamaepitys (L.) Schreb. subsp. chamaepitys. Arch. Biol. Sci., Belgrade 2015, 67, 1195-1202, https://doi.org/10.2298/ABS150225095J.

25. Boonya-Udtayan, S.; Thasana, N.; Jarussophon, N.; Ruchirawat, S. Serratene triterpenoids and their biological activities from Lycopodiaceae plants. Fitoterapia 2019, 136, https://doi.org/10.1016/j.fitote.2019.104181.

26. Vijayalakshmi, R.; Ravindran, R. Preliminary comparative phytochemical screening of root extracts of Diospyrus ferrea (Wild) Bskh. and Aerva lanata. Asian J Plant Science Research 2012, 2, 581-587.

27. Garima, S.; Sankar, P.; Muddasarul, H.; Varalakshmi, D.; Rukkumani, R. GC-MS Analysis, In Vitro Antioxidant and Cytotoxic Studies of Wheatgrass Extract. AJPCT 2014, 2(7), 877-893

28. Koushik, O.S.; Babu, P.S.; Karthikeyan, R. Isolation of Anticancer Bioactive and In Vitro Evaluation of Antioxidant and Anticancer Activity of Cynodon dactylon (L). Pers. Transl. Biomedical 2015, 6, https://doi.org/10.21767/2172-0479.100023. 